\title{
FOREST RESOURCES AND THEIR UTILIZATION IN COMMUNIST CHINA
}

\author{
BY JAN J. SOLECKI ${ }^{1}$
}

${ }^{1} \mathrm{Mr}$. Solecki is studying for his Ph.D. in the Dept. of Economics, University of Washington, Seattle, U.S.A. In June, 1963, he published a similar report on Russian forests and their utilization in The Forestry Chronicle. All other reference notes are appended.

\section{FOREST RESOURCES}

The forest covered area of Communist China is estimated variously at $5^{(1)}$ to $10^{(2)}$ per cent of the country's territory. One of the more recent publications, which appears to be in agreement with data accepted by FAO, gives an estimate of 8 per cent $^{(3)}$ compared with 51 per cent for the USSR, 45 per cent for Canada, 34 per cent for USA, 18 for India and 59 per cent for Japan. ${ }^{\left({ }^{(5)}\right.}$ (See Tables I and II.)

The main forest areas of Communist China are located in the North (See Map). Northeast China and the Eastern part of the Autonomous Region of Inner Mongolia have 60 per cent of the forest area of the country and 59 per cent of the forest stand ${ }^{(\mathbf{a})}$.

\section{TABLE I.}

Forest Areas of Communist China and Other Selected Countries ( 1,000 ha. $)$

\begin{tabular}{|c|c|c|c|c|c|c|c|c|}
\hline & \multirow[b]{2}{*}{$\begin{array}{l}\text { For est land } \\
\text { (total) }\end{array}$} & \multirow[b]{2}{*}{ Accessible } & \multirow[b]{2}{*}{ Inaccessible } & \multirow[b]{2}{*}{$\begin{array}{l}\text { Total } \\
\text { land area }\end{array}$} & \multicolumn{2}{|c|}{$\begin{array}{l}\text { Forest as } \\
\text { per cent } \\
\text { of land }\end{array}$} & \multicolumn{2}{|c|}{$\begin{array}{c}\text { Forest aren } \\
\text { per caput } \\
\text { (hectares) }\end{array}$} \\
\hline & & & & & All & $\begin{array}{c}\text { Access- } \\
\text { ible }\end{array}$ & $\begin{array}{c}\text { All } \\
\text { forests }\end{array}$ & $\begin{array}{c}\text { Access- } \\
\text { ible }\end{array}$ \\
\hline China & 76,000 & 28,100 & 48,500 & 976,101 & 8 & 3 & 0.4 & 0.04 \\
\hline USSR & $1,131,116$ & & & $2,240,300$ & 51 & & 5.5 & \\
\hline Canada & 417,674 & 186,595 & $231,079^{1}$ & 997,649 & 45 & 20 & 24.05 & 10.9 \\
\hline $\mathrm{USA}^{2}$ & 315,795 & 213,682 & 102,113 & 934,704 & 34 & 23 & 1.8 & 1.2 \\
\hline Brazil & 561,656 & 140,000 & 421,656 & 851,384 & 66 & 17 & 35.2 & 7.0 \\
\hline India $^{3}$ & 72,752 & 59,557 & 13,195 & 326,287 & 22 & 18 & 0.19 & 0.16 \\
\hline Japan & $23,040^{t}$ & 21,650 & 1,390 & 36,968 & 63 & 59 & 0.3 & 0.2 \\
\hline
\end{tabular}

${ }^{1}$ Accessible unproductive forests included

Including Alaska

${ }^{3}$ Figures for 1955

Figures for 1957

Source:

World Forest Inventory 1958. Food and Agricultural Organization of the United Nations. Rome, 1960. Table I, Pp. 60-69. 


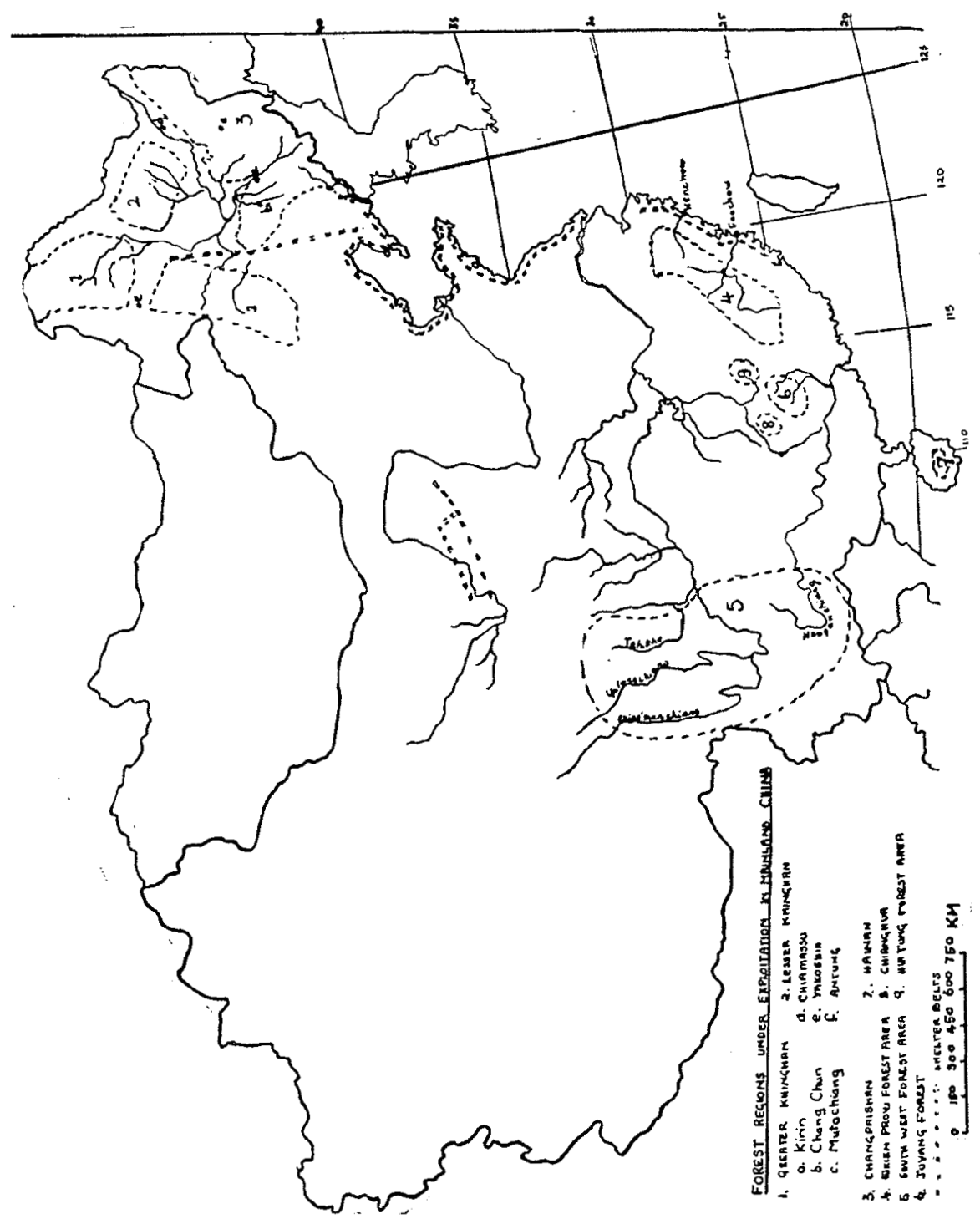


JUNE, 1964

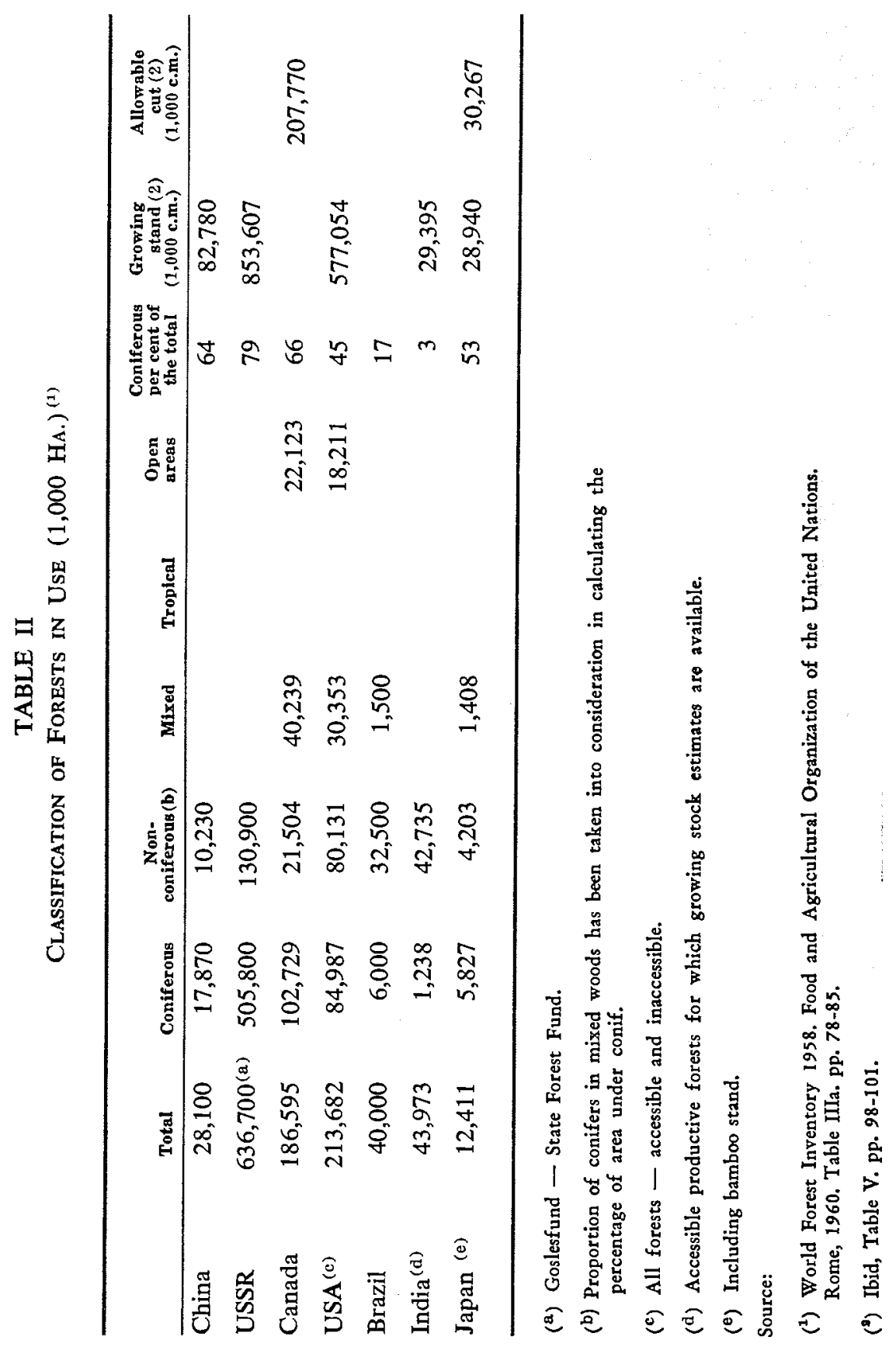


Unfortunately detailed up-to-date figures on forests by areas are not available. Table III gives such figures as compiled by the Nationalist Government before the war. These figures were provisionally accepted by $\mathrm{Ma} \mathrm{Chi}$, who said that they did not differ much from the estimates made by the Soviet experts ${ }^{(i)}$.

Of the total forest area of 76.6 mil. ha. (See Table I) approximately 56 mil. ha. are under state administration and the remaining 20 million ha. are administered by non-central government organizations ${ }^{(s)}$.

Communist China's inadequacy in forest resources can best be seen from per capita comparison with other countries. China has only 0.4 ha. of forest land per inhabitant whilst USSR has approximately 5.5 ha., USA - 1.8 ha., Canada 24.05 ha., Brazil 35.2 ha., India 0.19 ha. and Japan 0.3 ha. $^{\left({ }^{(}\right)}$

TABLE III

Forest-covered Areas and Areas Suitable for Afforestation in Communist China (in Ha.)

\begin{tabular}{|c|c|c|c|c|c|}
\hline $\begin{array}{l}\text { Names of } \\
\text { Regions }\end{array}$ & $\begin{array}{c}\text { Total } \\
\text { land area }\end{array}$ & $\begin{array}{l}\text { Forest Coy } \\
\text { in ha. }\end{array}$ & $\begin{array}{l}\text { overed area } \\
\text { Per cent of } \\
\text { total area }\end{array}$ & $\begin{array}{l}\text { Area suitable for a } \\
\text { in ha. }\end{array}$ & $\begin{array}{l}\text { afforestation } \\
\text { Per cent of } \\
\text { total area }\end{array}$ \\
\hline NE China & $153,155,880$ & $27,464,301$ & 21.26 & $34,255,503$ & 26.52 \\
\hline NW China & $292,331,640$ & $1,076,418$ & 0.17 & $85,435,254$ & 29.23 \\
\hline SW China & $212,175,040$ & $5,634,972$ & 2.66 & $72,203,994$ & 34.05 \\
\hline East China & $60,406,420$ & $8,806,095$ & 14.82 & $14,651,397$ & 24.66 \\
\hline \multicolumn{6}{|l|}{ Central and } \\
\hline South China & $106,350,720$ & $2,338,929$ & 2.20 & $32,148,217$ & 30.14 \\
\hline North China & $77,871,180$ & 35,523 & 0.05 & $22,038,651$ & 28.30 \\
\hline Total & $\overline{901,192,880}$ & $\overline{46,556,238}$ & 5.18 & $\overline{260,634,636}$ & 29.71 \\
\hline
\end{tabular}

Source: Lesa i Pochvy Kitaya p. 34 (Calculated on the basis of one urban mow $=0.06 \mathrm{ha}$ ).

\section{TIMBER Stand}

The timber stand of Communist China is also estimated variously by different people, from 4.9 billion c.m. ${ }^{(10)}$ to 5.15 billion c.m. (11) (12) approximately $8 \mathrm{c} . \mathrm{m}$. per inhabitant, compared with the USSR stand of 60.972 billion c.m. or 305 c.m. per inhabitant (See Table IV). The growing stand for various countries is given in Table II. From it can be seen that the growing stand of the USSR ${ }^{(13)}$ is approximately ten times greater than that of China, and that of USA six times greater. If calculated per caput the advantage lies even more with USSR and USA. Of the countries cited above only India appears to be worse off than China. The position of Communist China would appear somewhat better if the figure of 46.5 ha. $^{(14)}$ is taken as its exploitable forest area. This would give the annual growth of approximately 135 million c.m. and an allowable cut of at most 150 million c.m. It must be remembered, however, that a large percentage of the timber stand is inaccessible. FAO estimate that currently only 10 per cent of timber can be reached ${ }^{(15)}$. 
TABLE IV

FOREST UTILIZATION

Since 1950 China's cut of timber has been as follows: ${ }^{(1)}$ (in cubic metres).

\begin{tabular}{rrcccc}
\hline Year & c.m. & $\begin{array}{c}\text { Per cent of } \\
\text { growing stand }\end{array}$ & Year & c.m. & $\begin{array}{c}\text { growing stand } \\
\text { Per cent of }\end{array}$ \\
\hline 1950 & $6,640,000$ & 8.2 & 1956 & $20,840,000$ & 21.1 \\
1951 & $7,640,000$ & 9.2 & 1957 & $27,870,000$ & 33.7 \\
1952 & $11,200,000$ & 13.5 & 1958 & $35,000,000$ & 43.5 \\
1953 & $17,530,000$ & 21.1 & 1959 & $41,200,000$ & 49.8 \\
1954 & $22,210,000$ & 27.0 & 1960 & $47,000,000$ & 56.8 \\
1955 & $20,930,000$ & 25.3 & & & \\
\hline
\end{tabular}

The FAO estimate for 1960 cut, including fuel, was $58,500,000$ c.m., ${ }^{(17)}$ which is already considerably more than 70 per cent of the estimated growth, compared with only 56 per cent three years earlier, as shown in Table $V$ below. Bearing in mind poorly developed communications and the pressure exerted by the needs of industrialization, it is hard not to believe that there is a serious degree of overcutting in the more accessible areas. (Table $\mathrm{V}$ gives the removals in forests in use in Communist China and in other countries for the purpose of comparison. These differ somewhat from the officially released figures quoted above).

The urgent appeals, exhortations and measures for better utilization of forest products appear to confirm the view that there is an overcut. According to Chang Tse-ling "in the major forest zones e.g. southern slopes of Hsiao Hsingan-ling, the annual timber felling volume has exceeded the annual growth rate. If we adopt the negative approach of waiting for natural growth, the available forest reserves will have been practically exhausted in $40-50$ years. $\left.{ }^{(15)}\right)^{(10)}$

The rapid increase in the output of forest products is due primarily to the process of industrialization and modernization. It must be remembered that for every million tons of coal produced industry needs 22,000 cubic metres ${ }^{(20)}$ of timber pit-props alone, for every kilometre of new railways are needed 260300 c.m. of timber, ${ }^{\left({ }^{21}\right)}$ every 1000 square metres of new construction needs $100^{(22)}-130^{(23)} \mathrm{c} . \mathrm{m}$. of timber. In 1959 the output of machine made paper was $1,700,000$ tons, which required approximately $4.5-5$ million c.m. of timber products. Apart from these there is demand for timber in heavy industry, in light industry, in ship-building, for transport equipment and for general consumption.

To meet the growing demand remote forest areas are being gradually brought into exploitation and the output of the existing ones expanded. As already pointed out the main forest areas are located in the northeast, and it is here that the early increases in production took place.

In 1938 the Japanese estimated the forest area of Manchuria at 87.74 mil. ha. of which only one third, or 29.25 mil. ha. were covered with trees. The volume of timber stand was estimated at 3.7 bil. c.m. of which 1.5 bil. c.m. were coniferous trees and 2.2 bil. c.m. deciduous. ${ }^{(24)}$ 
This estimate is not too different from the one given in Table III of $\mathbf{2 7 . 5}$ mil. ha., especially considering the amount of forest cut in the period between the two estimates.

Before the war Japanese authorities had virtually taken over the forest industry in Manchuria and at the end of the Second World War there were approximately 150 sawmills located in lumbering areas with a total capacity of $3,922,800$ c.m. ${ }^{(26)}$ Although the Russians have dismantled most of the equipment in the major plants it is likely that the smaller ones escaped relatively unharmed. Thus Communist Chinese inherited in Manchuria skilled labour, some equipment and machinery and transport facilities which helped in rehabilitating the industry.

It is estimated that between 1931 and 1945 Japanese cut out 2 million ha: of forests, taking out over 100 million c.m. of timber or approximately seven million c.m. per year. ${ }^{(20)}$ This is less than one third of what is being taken out from this area at present.

The forests of the northeast can be divided roughly into:-

(i) Khingan (Hsingan ling) Mountains area from where the timber is transported to plants in Kirin, Chang-chun, Mu-ta-chiang and Chia-ma-ssu. Since 1949 forest industry here has been rapidly developed. By 1961 forty $^{(27)}$ lumbering centres have been set up in Heilungkiang and a dozen in the Great Khingan Mountains. In the latter over 1,000 large and small factories have

TABLE VI

Timber Reserves of Communist China (IN MIL. C.M.)

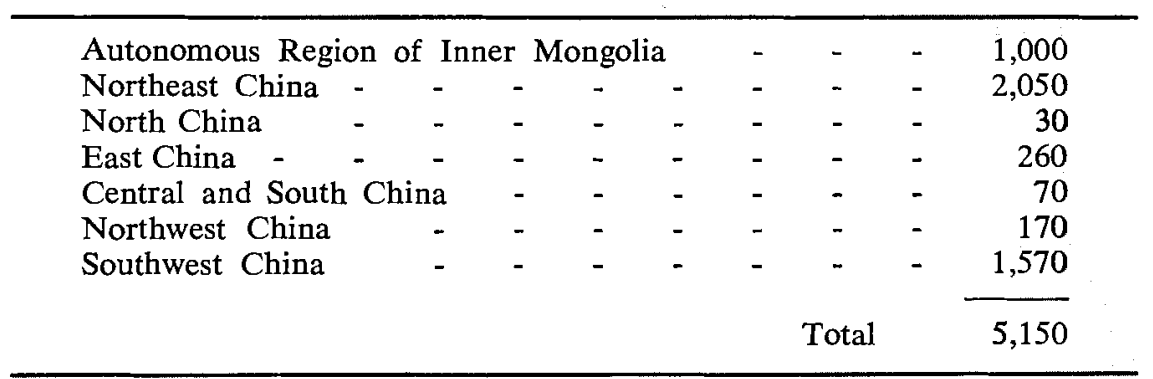

Source: Lesa i Pochvy Kitaya p. 35. (Calculated on the basis of the forest area being equal to approximately 750 mil. urban mow, or $46,556,238$ ha. as shown in Table III).

been set up for processing timber. ${ }^{(28)}$ The industry is equipped with electric and motor saws, tractors, hoists, skidding equipment, trucks and forest railways. Already in 1955 there were 69 state operated timber mills located near the forest area of Lesser Khingan. ${ }^{(20)}$ Near the timber areas towns have grown up such as Yakoshih, Tailing and Kingho. According to recent reports the southern slopes of Lesser and Great Khingan ranges have already been brought under exploitation and in future work will be extended to the northern slopes. ${ }^{(30)}$

By 1959 there were 76 lumbering enterprises in northeast China and Inner Mongolia producing approximately half the timber output of the country, ${ }^{(8)}$ 
or about 20 million c.m. Although in absolute terms the volume of timber coming from the northeast has been increasing, the area's share in the national total has declined from about 60-70 per cent in 1955 to 50 per cent in $1959 .{ }^{(39}$ )

(ii) Changpaishan range, from where timber is floated on the Yalu to Antung, is the other forest area of the northeast. As with Great and Lesser Khingan ranges the southern slopes here have already been brought under exploitation and at present attention is being diverted to developing the northern slopes. ${ }^{(33)}$

Outside of northeast China following are important forest processing areas.

(a) The mountains of Fukien province with the processing centres in Foochow and Wenchow to which timber is floated along the Minchiang and Ouchiang. During the past few years $800 \mathrm{~km}$. of highways, $48 \mathrm{~km}$. of railways and 200 $\mathrm{km}$. of new spur railway lines have been built here. ${ }^{(3)}$ A little to the south lie the Huashan and Tyanshan ranges. Their processing centre is Hanchow to which timber is floated along the Chiantanchiang.

(b) In Szechwan province in the region of the Tatukhe the forest stand is over 250 million c.m. Output over the last ten years amounted to $101 / 2$ million c.m. ${ }^{(35)}$ Here in Szechwan and Yunnan provinces in the timber areas lying in the basins of the Kinsha (Upper Yangtze), Tatukhe, Yalungchiang, Nanpanchiang and Chinshanchiang were built 21 lumbering and transport enterprises by $\left.1959 .{ }^{(30}\right)$ The total number of enterprises planned for this area is $36 .^{(37)}$

(c) The forest industry of South China is located in Hunan, Yunnan, Kwangtung and Kwangsi provinces. These regions have received special attention in the last three to four years. Access roads have been built to Juyang forest in Kwangtung west of town of Chiuichian. Of importance are also forests on Hainan Island, (s)

In Hunan the areas under development are Chianghua in the upper reaches of the Hsiaoshui and Huitung in the upper reaches of the Leishu.

Concrete figures as to the equipment and the degree of mechanization of the timber industry in Communist China are lacking, but these cannot be very high. Between 1952 and 1957 output increased by approximately 15 million c.m. while the reported number of automatic saws went up by 509 units, tractors by 871 units and trucks by 640 units. ${ }^{(30)}$

With the development of the timber industry, plants were also constructed for the processing of timber. Thus in 1959 there were under construction lumber machinery plants in Harbin, Mutachiang and Kuanhsien. One of the most important of these is the composite timber processing plant (combine) in Yuhao in Heilunkiang with modern equipment and capable of handling different kinds of timber. When completed it will have ten departments including lumbering, processing of timber, fibre-board and plywood manufacturing, lumber hydrolysis, pine extract refining and its own power station. ${ }^{(10)}$

Another combine was being built in Yakoshih with the help of East Germans who supplied the equipment. It was to have, among others, a tannin department which, when completed, will produce 5,000 tons of high grade tannin from 
larch bark per year. ${ }^{(41)}$ Yet another combine will be built in Foochow. Under construction were also Nanp'en wood hydrolytic plant. Tiehli wood dyhydrating plant and a number of smaller-below norm-plants, such as Hainan and Hopei fibre-board factories, Hopei Liuhsiao acetic acid plant, Wuhu Plywood factory, Kweiyang lumber mill and others.

From party and press there has been continuous pressure for better use of raw materials. It was reported that in response to exhortations 200 small factories were formed by the beginning of 1959 to utilize twigs, sawdust, bark, undergrowth and even weeds. ${ }^{(12)}$

In 1958 a campaign was launched for the establishment of tannin and fibreboard plants throughout the country to utilize forest rejects. By July 1960 there were already 200 fibreboard plants in existence, ${ }^{(33)}$ and considerably more tannin factories as there were reported 7000 tannin and fibreboard plants in Fukien alone, another 500 in the Sunhuachiang (Sungari) basin and 31 in Tibet. However, judging by speed with which they were put up, their output is likely to be very primitive and of dubious usefulness. ${ }^{(4)}$

\section{REFORESTATION}

As can be seen from Table III, in China the area suitable for afforestation is nearly six times greater than that covered with forests. Deforestation of China, which was a cumulative process extending back over many centuries, increased in recent decades. The reason's for this acceleration in cutting are a rapid rise in population, resulting in attempts to bring more marginal land under cultivation, chaos arising from rebellions, civil wars and wars, increased demand for timber with urbanization, industrialization and railway construction and finally exploitation of China's forests by foreign powers, e.g. Russia and Japan.

Deforestation of hillsides resulted in very rapid flow off of rain water leading to sudden changes in river levels, often disastrous to crops and settlements. The flow off also washes away soil from hillsides and terraces. The magnitude of this erosion is difficult to imagine. For example the Hwangho water contains 11-12 per cent of dry residue. In 1934 this river carried to Shanchow nearly one and half million c.m. of matter which represents a soil strip one metre deep, $15 \mathrm{~km}$. wide and $100 \mathrm{~km}$. long. Yangtze carries away annually over 220 square kilometres of soil one chi deep ${ }^{(5)}(1 \mathrm{chi}=32 \mathrm{~cm}$.)

Almost immediately on coming to power the Chinese Communists turned their attention to the problem of afforestation, mainly in response to urgent need but also undoubtedly following the example of Russia, where afforestation and shelter belt planting have received considerable attention.

Already in 1950 the Minister of Forestry, Liang Hsi, claimed that afforestation covered 110,000 ha. ${ }^{(10)}$ In 1952 Kao Kang initiated in northwest China the planting of a shelter belt $1100 \mathrm{~km}$. long with an area equal to one third of England, ${ }^{(47)}$ while Liang Hsi called for afforestation of 50 per cent of the barren hills of China within 30 years. ${ }^{(4)}$ 
In September 1953 the State Administration Council promulgated a "Directive on Mass Afforestation, Cultivation of Forests and Protection of Forests" which aimed at afforesting barren hills and wasteland, within the limits of natural conditions and manpower during 12 years beginning from $1956 .^{\left({ }^{(0)}\right)}$ In January 1956 a 12 year plan of afforestation was adopted providing for afforestation of 105 million ha. By the end of the period forests were to amount to 18 per cent of the country's surface and provide 15,700 million c.m. of timber. There was to be a big increase in tea oil, tung oil, walnut, Chinese cinnamon, varnish and other trees. ${ }^{(50)}$ Of 105 million ha. 66 million were to be planted with forests, 30 million with mulberry, fruit etc.

The Chinese Communists claim that they afforested:$1,350,000$ ha. before the first Five Year $\operatorname{Plan}^{(\pi)}$ $10,300,000$ ha. during the First Five Year Plan ${ }^{(\infty)}$ $40,000,000$ ha. during the first ten years of the regime's rule. ${ }^{(5)}$

By the end of 1958 the afforestation area in China was stated to have reached approximately 27.5 million ha. ${ }^{(\omega)}$ Target for 1959 was set at 26.6 million $^{(55)}$ ha. and for $1960-12$ million ha. ${ }^{(50)}$

With the passage of time and events, shifts have occurred in the afforestation programs. In the earlier stages afforestation was looked upon as a "climatic remedy" to reduce the erosion of soil through planting of trees on the mountain sides and river banks as a measure for immobilizing shifting sands and also as shelter belts against storms from the sea and from the deserts.

One of the largest and earliest is the already mentioned shelter belt initiated by Kao Kang in NE China, which covers 660,000 ha. It extends roughly from the Great Khingan Mountains along the borders of Heilunkiang and Kirin provinces where they adjoin Inner Mongolia to Liaotung Peninsula in the South, ${ }^{(67)}$ a distance of $1200 \mathrm{~km}$. Another large forest belt extends $600 \mathrm{~km}$. along the Great Wall from Tunghuanghsien in Kansu, across Ninghsia to Yulinhsien in Shensi. It serves as a protection against sand storms from the Gobi desert. ${ }^{(5 s)}$ A third large shelter belt was started in northwest China in 1958. When completed this belt will extend in a "V" shape over $650 \mathrm{~km}$. skirting the Tungri desert. It will run parallel to the Hwangho from Chungweihsien northeastwards to the north border of Ninghsia region and then turn southeast to link up with the shelter belt in the adjourning Shensi province. ${ }^{(50)}$ In South China shelter belts were planted along the coast to protect land from storms blowing from the sea. These belts have been planted some time ago. The Chinese claim that by now planted trees are $8 \mathrm{~m}$. tall in Manchuria and 10 $\mathrm{m} .{ }^{(0)}$ tall along the sea coast. More recently shelter belts have also been planted along the coast in East China. ${ }^{(01)}$

During the next stage more emphasis was placed on planting fast growing timber trees and oil and fruit bearing trees. People were encouraged to plant seedlings of selected varieties rather than to sow trees. It was claimed that by selection of appropriate species and correct planting the growing period could be reduced. For example, for fir it could be cut from 20-30 years to 10-20, while at the same time the yield per mow $(0.061$ ha.) could be increased from $10-20 \mathrm{c} . \mathrm{m}$. to $40-50 \mathrm{c.m} .{ }^{(02)}$ It was also claimed that "in terms of rate of 
growth planted forests grow 4-6 times faster than natural and a timber felling cycle of 40 years is possible instead of one of $100-120$ as is the case with natural forests. (A tree with a diameter of $30 \mathrm{~cm}$. is considered to be a mature one). ${ }^{(63)}$

In more recent times special stress has been laid on planting industrial timber producing trees near the points of demand. Thus in Spring 1961 many communes near coal mines planted trees for pit props. For example near Fushun large areas were planted with trees. In northwest and north China trees were planted for fuel. ${ }^{(0)}$

The difficulty in satisfying demand for timber is also reflected in exhortations by the government to use substitutes such as grass, bamboo and waste and also in recommendations that special measures should be taken to insure the utilization of small diameter timber (from tops and branches). This was to be achieved through the introduction of differentiated norms for wages and for plan fulfillment in terms of large and small diameter timber, ${ }^{(\pi)}$ though such measures would undoubtedly involve considerable administrative difficulties.

It is interesting to note that trees are planted also on agricultural land suitable for other purposes as the government recommended interplanting of trees with annual crops until such time as they form a crown. ${ }^{(\infty)}$

Although afforestation is carried on essentially with "Popular Support" labour the government exercises supervision and provides technical advice and the necessary seeds and equipment. During the period 1950-55 expenditure on seeds, afforestation and forest protection amounted to 440 million Yuan ${ }^{(07)}$. At the beginning of 1963 there were in the country 588 tree farms with a minimum area of 10,000 mow (600 ha.), 23 of which were over 100,000 mow (6,000 ha.). There were 2,100 state forestation farms (113 of them mechanized) employing 150,000 people. Apart from these there were 11,000 forest farms run by communes and brigades employing 80,000 people. During the past 13 years the government has spent 30 Yuan per mow on reforestation. ${ }^{(8)}{ }^{\infty 8)}$ Special centres have been set up in various provinces and regions to organize the collection and distribution of seeds and saplings. ${ }^{\left({ }^{(0)}\right)}$ In high areas difficult to reach, as for example in Szechwan, tree-seeds have been scattered from aircraft. ${ }^{(\pi)}$

Most forest planting appears to be done by mobilizing the local population. For example on November 5th 1959 Peking Radio reported that in carrying out the autumn afforestation campaign $2,100,000$ young people participated in the effort in Kansu, one million in Heilunkiang where they planted 650,000 mow of forest and 1,280,000 young people turned out in Kaifeng administrative district to plant trees in the old Yangtze river course and along the Lunghai railway. ${ }^{(2)}$ The week from March 30th to April 5th has been proclaimed National Afforestation Week when trees are planted in towns and villages. ${ }^{(7)}$

To promote the study of forestry, Forest Colleges were established in 1952 in Peking, Nanking and Harbin and departments of forestry set up in 13 universities. By 1957 the number of students reached 5-6,000 with approximately 800 graduates annually. In 1957 there were 26 forestry technical and 
middle schools with $16-17,000$ students, providing trained personnel for the forest farms and forest management institutes. ${ }^{\left({ }^{(4)}\right)}$

Forest protection also received attention. Anti-fire strips were cleared, observation towers constructed and protection from the air organized. Future plans provide for construction of access roads and purchase of fire-fighting equipment. ${ }^{(75)}$

The afforestation program has not proceeded without headaches. It was admitted that the quality of afforestation and regeneration work was low. Forests were cut or destroyed by fires faster than they could grow. While afforestation was stressed, protection and improvement of forests was neglected. As a result the low standards of forest cultivation were preserved and the existing forests were to a certain extent depleted.

Not all forestation plans conformed to needs. Timber requirements of different sectors of the economy were neglected. Plans were not implemented in accordance with local conditions, as a result trees planted did not correspond to needs. Land, after having been reforested, was reclaimed (for agriculture) or given over to grazing. Some localities ignored climatic and soil conditions, consequently incurring losses. ${ }^{(70)}$

Perhaps the best indication of how and why things went wrong can be obtained from the study of recommendations for the future, which can be summarized as follows:

a. Afforestation should be planned on the basis of Five Year Plans and not from year to year.

b. There should be unified management at the top but lower down in the administration felling and regeneration should be separated, with local population made responsible for the latter through underwriting set tasks.

c. Technical Forest Stations, of which there were 5000 in 1957, which have since been neglected, should be reactivated.

d. Long-term interest free loans should be granted to forest growing teams.

e. In view of the long period of growth, the state should help collective farms with saplings and subsidies for wages.

f. Ownership of forests should be assigned to those who cultiviate them. ${ }^{\left(\tau \pi,{ }^{78}\right)}$

In spite of obvious shortcomings due to bureaucracy, conflicting pressures and interests, it is very likely that afforestation is making a positive contributo Communist China's economy. It must be realized that here situation is very much different from agriculture. There collectivisation and communication resulted in a shift from highly intensive cultivation of land with individual incentives inbuilt to a less intensive system with no incentives and rank mismanagement. In forestry, in most cases, it was primarily the question of planting something where nothing grew before. However, due to the mass participation method it can be expected that only easily accessible areas are receiving attention while lack of transport, equipment and funds will lead to a neglect of more distant ones. Also, afforestation of barren hillsides and marginal lands makes possible to claim large acreages and distracts attention from the need for reforestation in the newly cut forest area. Finally with an acute shortage of fuel will the newly planted forests survive once the initial enthusiasm and vigilance have passed? 
Even though shelter belts and erosion-preventing forests may have some effect, it is very doubtful that the afforestation and reforestation undertaken will make up for the current overcut and they certainly will not provide sufficient forest products to satisfy future needs.

The trouble with statistical reports from totalitarian countries is that they tend to give the figures submitted by enterprises the benefit of the doubt in order to be able to claim maximum success. The greater the pressure from above, the less accurate statistics, the higher the claims. Usually the exposure of failures comes later when it is time to harvest the results of earlier efforts. By such time the statistics are published, credits claimed and prizes distributed. The figures of the Great Leap Forward constitute one of the best illustrations of this state of affairs. The results of bad reforestation will not be apparent for a decade or more but afforestation is probably making the countryside around towns look greener even now, thus giving an impression that all is well.

\section{Pulp and Paper Industry}

Even though the Chinese invented the method of paper production in the 2nd century A.D., in the recent past China has imported annually between 80-100,000 t. of paper. The largest output of machine made paper before 1949 was in 1943 , amounting to $165,000 \mathrm{t}$. The variety produced was limited and newsprint, printing paper and technical varieties were produced in amounts well below requirements. ${ }^{(70)}$ The principal paper and pulp producing centres were large ports (Shanghai had 20 per cent of country's total paper making capacity) ${ }^{(80)}$ and especially Manchuria, where before the war production capacity amounted to 126,000 tons of pulp and 76,000 tons of paper ${ }^{(51)}$ —not counting very small production units. As with the timber industry, there took place in Manchuria a large scale dismantling of machinery and equipment. Nevertheless at the end of the war production capacity was available for approximately $100-115,000$ tons of pulp and $50-60,000$ tons of paper. ${ }^{(2)}$ It is reasonable to suppose that most of this capacity was quickly mobilized after 1945 as by 1949 output of paper (for the whole of China) amounted to 108,000 tons. From this time on till the end of the First Five Year Plan a large part of the increase in production was attained through greater utilization of the exsisting capacity $(330,000$ out of 500,000$){ }^{\left({ }^{(3)}\right)}$

In view of the growing needs for paper, efforts were made to increase capacity. Indeed, instead of 10 plants as planned, a total of 23 were built or modernized and the capacity increased by 347,000 tons instead of 90,000 tons as planned. ${ }^{(s)}$ Because of the shortage of wood efforts are being made at present to use bamboo, rice and sugar cane stalks and waste. It is reported that by 1957 stalks from annual plants provide 70 per cent of raw material for paper, while wood pulp only 30 per cent, almost half of which was branches, tops and other rejects. Output of straw pulp rose from 16,500 tons in 1949 to 560,000 tons in $1958 .^{\left({ }^{85}\right)}$

Before 1949 only 22 types of paper were produced but by 1957123 types were manufactured including such varieties as condenser paper, waterproof, insulating and hard fibre papers and various types of card-board as well as a range of newsprint, printing and technical drawing paper for industry. Since 
1954 China has even been exporting newsprint to Vietnam, India and other countries. It was planned to export 32,000 tons already in 1955 ( $^{(8)}$

Since 1949 a number of plants have been constructed for the production of paper and other similar products. The most important of these is the one at Chia-ma-ssu, which was built with Russian assistance and completed in November 1957. Its production capacity was said to be 50,000 tons of technical paper (including cement bags and cable insulating paper) per year. It will have a separate department for the production of copper wire for paper making machines. ${ }^{(57}$ ) This plant is one of the 156 key projects built with Russian help.

Another important objective is Kwang-chou plant near Canton, which after recently completed reconstruction with Russian and GDR technical help became the largest in the country. Its capacity is 60,000 tons of newsprint and 15,000 tons of cardboard. ${ }^{\left({ }^{89}\right)}$

In Anhwei province a factory was commissioned for the production of cigarette paper. Other plants under construction or recently completed are: Chifeng in Inner Mongolia (capacity 10-12,000 tons per year of paper), ${ }^{(50)}$ Kaili in Kweichow (capacity 7000 t. of newsprint per year), Hua-feng plant in Hanchow (a new department added for the production of cellophanecapacity 17 tons per day), Nanp'ing (capacity $100 \mathrm{t}$. per day of paper), ${ }^{(\infty)}$ Chiameng in Kwangtung, which will use sugar-cane stalks from the largest sugar refinery in China, "Peitse", to produce 40,000 tons of cellulose and 17,000 tons of softboard tiles. Yingkow mill in Liaoning, one of China's biggest paper mills produces on the average 200 tons of paper a day with a record of 400 per day. ${ }^{(1)}$ At Paoting, capital of Hopei, a factory was under construction in 1957 for the production of high grade paper. Machinery for it was obtained from East Germany. Its planned capacity was given as 7,600 tons of paper per year. ${ }^{(\infty)}$

As demand for paper was growing faster than the production capacity of large plants a considerable number of medium and especially small size plants were built. In 1958 a decision was taken to have 10,000 of them run by communes. Their aggregate output was to be 3-5 million tons of paper. ${ }^{\left({ }^{(a)}\right)}$

The consumption of paper in Communist China per caput was 5.5 lbs. in 1959 compared with 34.4 lbs. for the USSR, $280 \mathrm{lbs}$. for Canada and $438 \mathrm{lbs}$. for USA. (See Table VII). With the spread of education, industrialization and modernization there will be an increase in demand for paper. Undoubtedly more paper will be produced from substitutes, but it must be remembered that none of the materials which could be used as substitutes for wood have been wasted in the past. Bamboo, kaoliang, rice, soya bean stalks and ordinary grass are used as building materials, as fuel or as fertilizers. In order to use them in a significant scale replacements must be found for them in their present use. In an economy of extreme scarcity, as is the case in China, India and other similarly situated countries it is not easy to find unused natural resources without incurring large expenditures on transportation or development. It may prove cheaper for China to import wood than fuel or fertilizers. 
TABLE VII

Output and Per Caput Consumption of Paper in $1959^{(1)}$

\begin{tabular}{lcc}
\hline & $\begin{array}{c}\text { Output } \\
\text { million } \\
\text { tons }\end{array}$ & $\begin{array}{c}\text { Consumption } \\
\text { lbs. }\end{array}$ \\
\hline U.S.A. & 34.1 & 438 \\
Canada & 8.6 & 280 \\
USSR & 3.4 & 34.4 \\
C. China & 1.7 & $5.5^{(2)}$ \\
\hline
\end{tabular}

(1) Geza Ifju, Statistics on Pulp and Paper. Soviet Forestry. Proceedings of the Interfaculty Seminar on Forest Resources in the USSR and Their Utilization. U.B.C., Vancouver, 1963. Ed. J. A. Crosse and J. J. Solecki.

(2) Exports not counted

\section{General Survey and Conclusion}

Both the Nationalist and the Chinese Communist governments have condemned the Japanese for their predatory exploitation of northwest forests. Yet the latter cut only seven million c.m. per year, while the present cut for the same area must be near to four times that amount.

By 1967 Chinese Communists plan to produce 510 million tons of coal, for which they will need over ten million c.m. of wood for pit props. The length of railways in 1960 was $35,000 \mathrm{~km}$. requiring well over a million c.m. of wood for rail sleepers to replace the ones already on the track, ${ }^{(0)}$ plus whatever will be necessary for new construction and for forest industry railways. In the same year housing construction from government capital investments alone required approximately 2.6 million $^{(06)} \mathrm{c.m}$. of timber. To this must be added industrial constructions and housing paid not from government budget. The increase in publications as shown in Table IX below will lead to a greater demand of paper.

According to experts of the Scientific Institute for Prospective Studies of the Ministry of Foreign Trade of the USSR the shortage of wood in China will continue to grow. It will amount to 7 million c.m. in 1962, 15 million c.m. in $1967,38.5$ million c.m. in 1972 and 39 million c.m. in 1977. ${ }^{(08)}$

Wilfully misled by their own propaganda on the possibility of rapid growth of forests and the effects of natural and artificial afforestation the Chinese Communists have been cutting out forests at a very rapidly increasing rate. In a planned economy fulfillment of plans is always the most important thing at a given time; the future, when not immediately manifest, is often allowed to take care of itself. In 1955 it was said that "each year the quantity of timber abandoned in the area where trees are felled and in timber processing plants is almost equal to, or even exceeding the production of raw wood. The loss is tremendous". ${ }^{(97)}$ In 1960 Jen Min Jih Pao complained that in spite of all the exhortations over 30 per cent of timber was still being wasted on the spot and a further 15 per cent in the course of processing. ${ }^{(8)}$ 
TABLE VIII

Output of Paper in Communist China (in 1,000 t.)

\begin{tabular}{rrrr}
\hline 1943 & $162^{1}$ & 1955 & $589^{1}$ \\
1949 & $108^{1}$ & 1956 & $746^{1}$ \\
1952 & $372^{1}$ & 1957 & $912^{1}$ \\
1953 & $427^{1}$ & 1958 & $1,220^{2}$ \\
1954 & $556^{1}$ & 1959 & $1,700^{3}$ \\
& & 1960 & $2,240^{4}$ \\
\hline
\end{tabular}

Sources:

${ }^{1}$ Razvitie Ekonomiki i Vneshneekonomicheskikh Svyazei K.N.R. p. 211.

${ }^{2} \mathrm{Li}$ Tsui-yün. Director of the Bureau for Paper Making Industry, Min. of Light Industry. Ta Kung Pao. Hong Kong. 6th Oct., 1959. C.B. 601.

${ }^{3}$ Li Fu-chun. Vice-Premier. Report on the Draft 1960 Economic Plan. Peking, 30th March, 1960. C.B. 615 .

- Year Book of Forest Product Statistics, FAO. Rome, 1962, p. 68.

TABLE IX

Growth of Publications in Communist China (million copies)

\begin{tabular}{lrrrrrr}
\hline \multicolumn{1}{c}{ Year } & 1950 & 1952 & 1953 & 1954 & 1955 & 1956 \\
Newspapers & 798 & 1609 & 1672 & 1711 & 1954 & 2611 \\
Periodicals & 35 & 204 & 172 & 205 & 288 & 353 \\
Books & 275 & 786 & 755 & 940 & 1080 & 1786 \\
\hline
\end{tabular}

Source: Razvitie Ekonomiki i Vneshneekonomicheskikh Svyazei K.N.R. p. 555.

As already noted the reserves of the southern slopes of the main forest areas of northern China have already been brought under exploitation and now attention is being shifted to the northern slopes and also to the forest reserves in other parts of China, which have not been utilized in the past because of their remoteness. As can be expected, these are less productive areas with higher exploitation costs.

The timber deficiency in China will have to be made up essentially by imports for at present there is very little hope of replacing wood in construction by suitable metals or products from chemical industry because of the shortage of electric power and crude oil. Situation with respect to substitutes for wood pulp has already been pointed out.

The two likely suppliers of timber to China are the Soviet Union and North America, especially Canada. At first sight the Soviet Union appears to have an advantage, but this is not necessarily so. The timber stand of Eastern Siberia is needed for the processing centres recently completed or under construction on the Angara and the Yenisei rivers. In addition the cost of transporting timber to the North Sea and transloading it to ocean going ships in the short ice-free summer is likely to be rather high, while transport by rail would be even more so. The forest stands of the Far East (Maritime Province) on the other hand are primarily still underdeveloped mixed forests with very high 
costs of exploitation. Their proximity to the Chinese markets is also somewhat illusory. The Amur flows East and then North, where the handling of timber becomes difficult due to prolonged winters. Transport by rail, or small craft by water against the current, will be expensive.

On the North American side, however, conditions are much more favourable. Timber reserves are generally better than those of the Russian Far East and port facilities are available for handling large quantities all year round. The high cost of labour is offset by high degree of mechanization.

In view of the recent frictions between the USSR and the Communist China and the economic considerations shown above there is no reason to expect that Communist China will restrict itself in satisfying shortages of timber by: imports from the Soviet Union alone. There are distinct long term possibilties for the Canadian forest industry which it will be unwise not to examine with due care.

\section{Notes}

${ }^{1}$ Lesa i Pochvy Kitaya (Forests and Soils of China). Ed. N. P. Premezov, Moscow, 1955 (A translation of a book from Chinese, written by $\mathrm{Ma}_{\mathrm{a}} \mathrm{Chi}$ - The Forests of China and Liu Haipeng - The Soils of China. Henceforth referred to as Lesa i Pochvy Kitaya.)

"World Geography of Forest Resources. American Geographic Society. The Ronald Press Co., New York. 1956. Chapter on China by D. Y. Lin. pp. 529-550.

${ }^{3}$ Razvitie Ekonomiki i Vneshneekonomicheskikh Svyazei KNR (Development of the Economy and External Economic Relations of the Chinese People's Republic). Vneshtorgizdat (Foreign Trade Publications), Moscow 1959. p. 331.

"World Forest Inventory 1958. Food and Agricultural Organization of the United Nations. Rome 1960. Table I. pp. 60-69.

${ }^{5}$ Percentages given by the Chinese Communist Sources are: China 7.0 per cent, USSR 33.9, USA 32.8, India 21.6, Japan 61.8. The Forests in Our Country. Shih-Shih Shou Tse (Current Events) Peking, No. 6. March 25, 1956. Extracts from the Mainland Magazines. Prepared by the American Consulate General in Hong Kong. No. 41. Henceforth referred to as ECMM.

${ }^{6}$ Ekonomicheskaya Geografia Kitaya (Economic Geography of China). Izdat. Inostrannoy Literatury (Publication of the Foreign Literature)/Translation from Chinese/. Moscow 1957. p. 76.

'Lesa i Pochvy Kitaya. p. 34.

${ }^{8}$ Razvitie Ekonomiki i Vneshneekonomicheskikh Syyazei KNR. p. 331.

${ }^{9}$ World Forest Inventory. pp. 60-69.

${ }^{10}$ Razvitie Ekonomiki i Vneshneekonomicheskikh Svyazei KNR. p. 331.

${ }^{11}$ Lesa i Pochyy Kiraya. p. 35.

${ }^{10}$ Cheng Chung-teh in an article "Ten Years of Afforestation", Ti-lih Chih-shih (Geographical Knowledge) No. 8. August 1, 1959, estimated the timber stand of Communist China at 6.300 billion c.m. and the forest area covering 10.1 per cent of the country's territory. ECMM No. 189 pp. 30-34.

${ }^{13} \mathrm{~J}$. Solecki, Forest Resources and their Exploitation in the USSR. Forest Chronicle, June 1963. p. 215.

${ }^{14}$ As given in table III.

${ }^{15} \mathrm{FAO}$ estimate that only 10 per cent of the forests are accessible. See Table I-Forest Area per caput, Columns: "All forests". and "Accessible Forests".

${ }^{10}$ Figures compiled from the official Chinese Communist announcements and publications by US Department of Commerce. Percentages were computed on the basis of growing stand as given in Table II, i.e. $82,780,000 \mathrm{c.m}$.

1i Year Book of Forest Products and Statistics. FAO. Rome 1962. p. 9. 
${ }^{10}$ Chang Tze-liang, Party Secretary of Tai-ling Branch of the CC Northern Forestry Institute, "Develop Forest Reserves with Better Results". Hung Chi, No. 7. 1st April, 1959. pp. 46-47. JPRS 9193/59.

${ }^{10}$ It must be remembered that overcutting can be a result of a deliberate economic choice and therefore cannot be condemned as such. What is alarming in this particular case is that the forests are being cut at a fast rate under an illusion that they can be made to grow fast enough to make up the cut.

${ }^{20}$ An Important Way to Make Comprehensive Use of Timber. Jen Min Jih Pao, 17 Jan., 1960. S.C.M.P. 2189 pp. 2-5. Henceforth referred to as J.M.J.P.

1 Ibid.

${ }^{2}$ Ching Wen. Lumbering and Regeneration of Forests. J.M.J.P. 20 th June, 1961. S.C.M.P. 2529 p. 14.

${ }^{28}$ An Important Way to Make Comprehensive Use of Timber. J.M.J.P. 17th Jan., 1960. S.C.M.P. 2529 p. 14.

${ }^{24}$ Report on Japanese Assets in Manchuria to the President of the United States. Edwin W. Pauley, Ambassador of the United States and Personal Representative of the President on Reparations. p. 233.

${ }^{25}$ Report on Japanese Assets in Manchuria to the President of the United States. Edwin W. Pauley, Ambassador of the United States and Personal Representative of the President on Reparations. July 1946. pp. 233-236.

${ }^{20}$ Ya. I. Telegin, V. I. Potapov. Sel'skoye Khozyaistvo Kitaiskoy Narodnoy Respubliki (Agriculture of the People's Republic of China), All Union Society for the Dissemination of Political and Scientific Knowledge. No. 34. Moscow, 1958 p. 31.

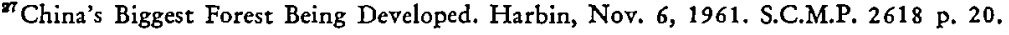

${ }^{29} \mathrm{Big}$ Expansion in Timber Felling Area in Northeast China. J.M.J.P. 22nd Jan., 1961. S.C.M.P. No. 2426.

Northeast Timber Industry Expands. Peking, 5th March, 1955. S.C.M.P. 1001 p. 29.

${ }^{30}$ Progress of Timber Industry in the Past 10 Years. Peking, Sept. 27, 1959. Current Background (henceforth referred to as $\mathrm{CB}$ ) No. 604. American Consulate General. Hong Kong.

81 Ibid.

Northeast Timber Industry Expands. Peking, 5th March, 1955. S.C.M.P. 100 1p. 29.

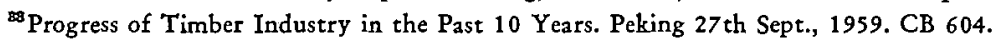

${ }^{34}$ New Lumber Areas Being Opened $U_{p}$ in South China. Foochow, 3rd Feb., 1963. S.C.M.P. 2914 p. 10.

${ }^{35}$ Lumbering Extends in South West China. Chengtu, 13 th Feb., 1963. S.C.M.P. 2921 p. 21.

${ }^{30}$ Progress of Timber Industry in the Past 10 Years. Peking 27th Sept., 1959 CB 604.

${ }^{87}$ Conference Decides on Measures to Increase China's Timber Output. Peking, 22nd March, 1959.

S.C.M.P. 1918 p. 20.

${ }^{2}$ Lesa i Pochvy Kitaya. p. 38.

${ }^{9}$ Razvitie Ekonomiki i Vneshneekonomicheskikh Svyazei KNR. p. 208.

${ }^{40}$ Capital Construction Work of China's Forestry Develops Fast. Peking, 5th Nov., 1959. S.C.M.P. 2135. p. 17.

${ }^{4}$ GDR Helps China to Build Lumber Products Plant. Yakoshih, 6th Oct., 1959. S.C.M.P. No. 2115 p. 8.

${ }^{4}$ Processing and Chemical Industry Grows in Timber Center. Yakoshih, 14th Feb., 1959. S.C.M.P. 1958.

${ }^{4}$ Growth of China's Fibreboard Industry. Peking, 4th July, 1960. S.C.M.P. 2293 p. 9.

'Tannin and Fibreboard in China's Forest Areas. 23 rd July, 1960. S.C.M.P. 2309 p. 19.

${ }^{45}$ Lesa i Pochvy Kitaya. p. 19.

${ }^{46}$ Liang Hsi. Big Success in Afforestation during 1950. J.M.J.P. 8th April, 1951. S.C.M.P. 92 p. 25 .

"Kao Kang. A Giant Shelter Belt for N.E. China. People's China. No. 6. Peking, 16th March, 1952. S.C.M.P. 303 p. 16.

${ }^{4}$ Liang Hsi. Forestry Work in China. J.M.J.P. 11 th June, 1952. S.C.M.P. 353 p. 8. 
${ }^{*}$ Hou Chi-cheng. The Role of Forestry in the National Economy. Ching-chi Yen-chin (Economic Research) No. 5. 17 th May, 1962. E.C.M.M. No. 320.

80 12-Year Plan of Afforestation Adopted. Peking, 17th Jan., 1956. S.C.M.P. 1212 p. 14.

51 1953 Plan for Large Scale Afforestation Adopted. E.C.M.P. 458 p. 21.

${ }^{60}$ Razvitie Ekonomiki Vneshneekonomicheskikh Svyazei K.N. p. 333.

The figure given is 450 million mow. Peking 17th Nov., 1958. S.C.M.P. 1920.

"China's Afforestation Target for 1959. Peking 9th March, 1959. S.C.M.P. 1972 p. 14.

${ }^{50}$ Growth of China's Fibreboard Industry. Peking, 4th July, 1960. S.C.M.P. 2293 p. 9.

${ }^{60}$ Vice-Premier Li Fu-chun's report on the Draft of the 1960 Economic Plan. Peking, 30th March, 1960. C.B. 615.

${ }^{6}$ Giant Shelter Belt Project Transforms Formerly Sand Ravaged Area of Northeastern China, 1 st June, 1961. S.C.M.P. 2512 p. 32.

${ }^{6}$ Ibid.

${ }^{\text {}}$ More Trees Planted in New Forest Belt in NW. China. Yinchuan, 5 th Feb., 1961. S.C.M.P. 2436 p. 14.

${ }^{\circ}$ Forest Belts Grown in China. Peking, 19th Aug., 1961. S.C.M.P. 2566.

${ }^{1}$ Coastal Shelter Belts in E. China. Foochow, 9th Sept., 1961. S.C.M.P. 2578 p. 13.

Cheng Chung-teh. Ten Years of Afforestation. Ti-li Chih-shih (Geographical Knowledge), No. 8. 1st Aug., 1959. E.C.M.M. 189 pp. 30-34.

${ }^{09}$ Chang Tse-liang. Party Secretary of the Tai-ling branch of the Chinese Communist Northern Institute. "Develop Forest Reserves with Better Results". Hung Chih. No. 7. 1 st April, 1959. J.P.R.S. $9193 / 59$.

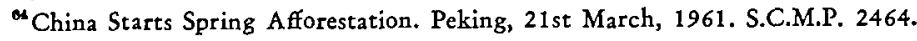

"Yang Yen-sen and Pai Ching-yi. "A Problem of Today's Timber Production." 10th Nov., 1961. E.C.M.M. 290 p. 20.

${ }^{e}$ Cheng Chung-teh. 10 Years of Afforestation. (Geographical Knowledge.) No. 8. 1st Aug., 1959. E.C.M.M. 189. pp. 30-34.

*The Forests in Our Country. Shih-shih Shou-tse (Current Events.) Peking, No. 6. 6th March, 1956. E.C.M.M. 41.

${ }^{*}$ State Tree Farms in China. Peking, 29th July, 1961. S.C.M.P. 2551. p. 27.

${ }^{\infty}$ Summing Up Forestation Work in the Past 13 Years. Chung-Kuo Lin-yeh (Chinese Forestry). No. 5. May, 1963. E.C.M.M. 367.

${ }^{70}$ China Sets Up Supply Centres for Tree Planting. Peking, 19th Nov., 1962. S.C.M.P. 2865 p. 12.

${ }^{7}$ Aerial Sowing of Tree Seeds in South West Provinces. Chengtu, 9th Aug., 1962. S.C.M.P. 2799. p. 16.

"A Powerful Afforestation Campaign Gains Momentum Throughout China. Peking, 5th Nov., 1959. S.C.M.P. 2135 . p. 17.

${ }^{r}$ Canton Municipal People's Council Call Upon the People to Take an Active Part in Planting Trees and in Afforestation Activity. Nan-fang Jih-pao. Canton, 31 st March, 1962, S.C.M.P. 2724.

"Education in Forestry Develops Fast in Our Country. Kuang-ming Jih-pao, 13th Oct., 1937. S.C.M.P. p. 20.

${ }^{73}$ Razvitie Ekonomiki i Vneshneekonomicheskikh Svyazei K.N.R. p. 335.

"Summing Up Forestation Work in the Past 13 Years. Chung-kuo Lin-yeh (Chinese Forestry), No. 5. 6th May, 1963. E.C.M.M. 367.

I Ibid.

${ }^{78}$ Rather difficult to visualize under the present conditions in China.

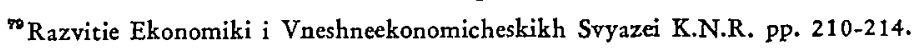

${ }^{\circ}$ Chou Li. To Overcome Raw Material Shortages in Paper Manufacturing in Shanghai. Shanghai, 1st Dec., 1956. S.C.M.P. 1433. p. 17. 
${ }^{81}$ Report on Japanese Assets in Manchuria. pp. 226-232 and Appendix 13.

62 Ibid.

${ }^{93}$ Razvitie Ekonomiki i Vneshneekonomicheskikh Svyazei K.N.R. pp. 210-214.

Bt Ibid.

${ }^{85} \mathrm{Li}$ Tsai-yun. Director of Bureau for Paper Making Industry, Ministry of Light Industry. China Home of Paper Making. Hong Kong $T_{\mathfrak{a}}$ Kung-pao. 6ch Oct., 1959. C.B. 601.

${ }^{80} \mathrm{Big}$ Increase in Newsprint Export. Pekin, 26th April and 5th June, 1955. S.C.M.P. 1062.

${ }^{s i}$ Razvitie Ekonomiki i Vneshneekonomicheskikh Svyazei K.N.R. Pp. 210-214.

${ }^{33}$ Ibid.

${ }^{s 0}$ Ibid.

${ }^{00}$ New Paper Mill in Fukien. Foochow, 17th July, 1956. S.C.M.P. 1333. (This report gives the capacity of this mill as $200 \mathrm{t}$. of paper per day).

${ }^{01}$ China's Output of Paper Grows. 7 th Sept., 1957. S.C.M.P. 2095. P. 9.

${ }^{02}$ New Paper Mill Under Construction on Hopei Province. Paoting, 12th April, 1957, S.C.M.P. 1512. p. 22.

${ }^{83}$ Razvitie Ekonomiki i Vneshneekonomicheskikh Svyazei K.N.R. pp. 210-214.

${ }^{04}$ This estimate takes into account that by mid-1962 75 per cent of railway sleepers in China were treated, giving them life expectancy of 10-13 years. (Peking 29th July, 1962. S.C.M.P. 2792 p. 22). There are railway sleeper treating plants in Harbin \& Wuhan. Ya. N. Guzovaty. "U Karty Mira" (By the World Map), Moscow, 1956.

${ }^{6}$ In 1960 housing construction paid for from Government budget amounted to 26.4 million sq. m. Ekonomika Stran Sotsialisticheskogo Lagera v Tsifrakh (Economics of the Countries of the Socialist Camp in Figures), Sotsekgiz. Moscow, 1962. p. 145.

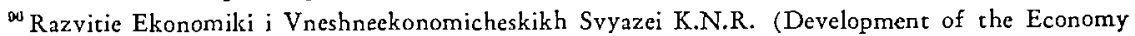
and External Economic Relations of the Chinese People's Republic). Published by Nauchnoisledovatel'nyi Kon'ykturnyi Institut MVT SSSR (Scientific Institute for Prospective Studies of the Ministry of Foreign Trade of the USSR). pp. 208-210.

${ }^{97} \mathrm{Lian} \mathrm{Hsi}$, Ministry of Forestry. The Forest Situation in China. A report delivered to the III Session of the First National People's Congress on 17th June, 1956. C.B. 407.

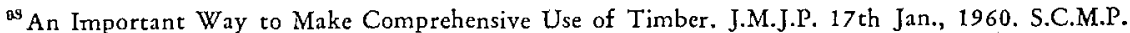
No. 2183 . pp. $2-5$. 